\title{
https://doi.org/10.46813/2020-130-140 \\ EMISSION CHARACTERISTICS OF GAS DISCHARGE PLASMA ON MIXTURES OF CADMIUM DIODIDE VAPOR, HELIUM AND XENON
}

\author{
A.A. Malinina, A.N. Malinin
}

\section{Uzhhorod National University, Uzhhorod, Ukraine}

The results of studying the spectral, integral, and resource characteristics of gas-discharge plasma radiation on multicomponent mixtures (cadmium diiodide with helium and xenon atoms) are presented. The creation of a gasdischarge plasma and the excitation of the components of the working mixture were carried out by a pulse-periodic (pulse repetition rate of $18 \ldots 20 \mathrm{kHz}$, pulse duration $\sim 150 \mathrm{~ns}$ ) barrier discharge. Radiation in the visible spectrum of exciplex molecules of cadmium monoiodide, cadmium atoms, xenon was detected. The regularities in changes in the emission characteristics of the plasma are established depending on the repetition rate of the pump pulses, the component and quantitative composition of the mixtures. Research data is of interest for creating a gas-discharge source that radiates simultaneously in the violet, green, red, and infrared spectral ranges.

PACS: 42.55.Lt; 42.60 Lh

\section{INTRODUCTION}

Plasma based on mixtures of cadmium diiodide vapor with inert gases is studied to create a highly efficient coherent and spontaneous (with a large area) source in the red spectral range of radiation for a number of scientific and technological applications [1-9].

In [2-6], it was found that in a barrier discharge in mixtures of cadmium diiodide vapor with inert gases and molecular nitrogen at frequencies of pump pulses of less than or equal to $6000 \mathrm{~Hz}$, intense emission of an exciplex cadmium monoiodide $\mathrm{CdI}^{*}$ molecule (transition $B^{2} \sum_{1 / 2}^{+} \rightarrow X^{2} \sum_{1 / 2}^{+}$with a maximum of radiation at wavelength $\lambda=650 \mathrm{~nm}$ ) observed . These experiments are limited to studying the plasma emission spectra and the dependences of the radiation intensity of cadmium monoiodide on the partial pressures of helium, neon, and nitrogen at low pulse repetition rates. The emission characteristics of a barrier-discharge plasma in multicomponent mixtures, the working life of mixtures at increased repetition rates of pump pulses (up to $20 \mathrm{kHz}$ ), and also the plasma parameters were not investigated.

This article presents the results of our studies on the emission characteristics and plasma parameters of a barrier discharge in mixtures of cadmium diiodide vapor with helium and small xenon additives at pump pulse repetition frequencies in the range of $18 \ldots .20 \mathrm{kHz}$.

\section{TECHNIQUE AND EXPERIMENTAL CONDITIONS}

Fig. 1 shows the main nodes of an exciplex gasdischarge radiation source in which a single barrier discharge was used to create a plasma on a working mixture of cadmium diiodide and helium vapor. The source design was cylindrical. The side surface of the discharge tube served as an operation radiation zone.

An exciplex gas-discharge radiation source was made of a quartz tube with a diameter of $16 \mathrm{~mm}$ and a length of $220 \mathrm{~mm} \mathrm{1}$. An electrode made of tungsten 2 of circular cross section with a diameter of $4 \mathrm{~mm}$ was placed in the middle of the tube along the axis. The second electrode - stainless steel 3 was perforated (with a transmittance of radiation of $50 \%$ ) located on the outer surface of the tube 1 . The thickness of the discharge region 4 and the burning length of the coaxial volume discharge are 12 and $216 \mathrm{~mm}$, respectively. The exciplex source is located in a quartz tube 5, which is welded at the ends, its length is $230 \mathrm{~mm}$, diameter $26 \mathrm{~mm}$. Atmospheric air was removed from the volume 6 between the exciplex lamp and the quartz tube 5. A pulsed periodic voltage from a pump source was applied to the electrodes 2 and 3 through the metal - quartz inputs 7 and 8 . The use in the design of an exciplex gasdischarge radiation source of a volume 6 from which the atmosphere was removed was caused by the need to ensure high values of the partial pressures of cadmium diiodide vapor in the discharge region 4 . They increased due to changes in the temperature of the working mixture. This design of the exciplex gas-discharge radiation source provided an increase in the energy characteristics of the radiation source by $40 \%$ compared to the design without volume 6 .

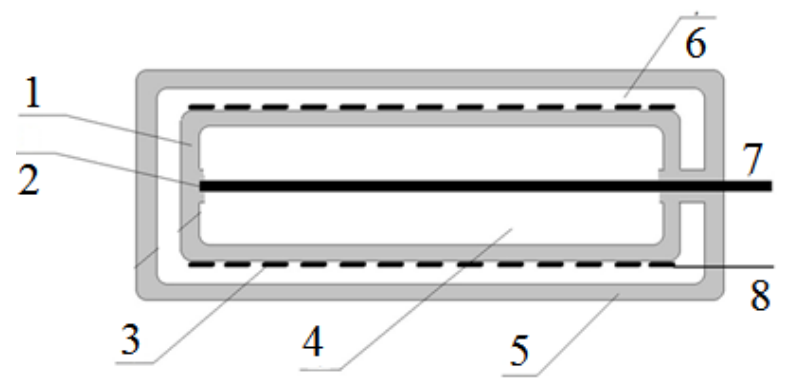

Fig. 1. The main nodes of the exciplex radiation source: 1 -quartz tube; 2 - electrode; 3 -perforated electrode; 4 -discharge region; 5 - quartz tube; 6 -vacuum region; 7,8 -electrical inputs

The discharge was excited by a mixture of cadmium diiodide vapor and helium in the discharge region 4 , the volume of which was $31 \mathrm{~cm}^{3}$ from a repetitively pulsed nanosecond pulsed generator. The generator provided the amplitudes of the pulse voltage (pulse duration $150 \mathrm{~ns}$ ) and current at the emitter electrodes at the level of $10 \ldots 20 \mathrm{kV}$ and $300 \mathrm{~A}$, respectively, the pulse repetition rate was $18 \ldots 20 \mathrm{kHz}$. 
The radiation was lead out from the central region of the interelectrode space and analyzed in the visible and near UV spectral regions using an optical system (ZMR-3 monochromator and FEU-79 photomultiplier). The spectral resolution of the ZMR-3 monochromator was $44 \AA$ at a wavelength of $\lambda=434 \mathrm{~nm}$. The optical system was calibrated by the radiation of a SI $8-200$ reference tungsten lamp at a filament temperature $\mathrm{T}=2173 \mathrm{~K}$.

The average radiation power was recorded with a "Quartz-01" device. The average power meter - the "Quartz-01" device and the KS-10 light filter were installed in the registration system instead of the ZMR-3 monochromator. To determine the radiation power from the entire surface of the exciplex source, we used the expression for the irradiance created by an equalbrightness radiating line, provided that its length is much less than the distance at which the photodetector is located from the radiation source [10].

$\mathrm{P}_{\text {rad. }}=\Omega_{0} \mathrm{P}_{\text {det. }} / \Omega_{\text {det. }}$, where $\mathrm{P}_{\text {det. }}$ power in $\mathrm{W}$ recorded by the photodetector; $\Omega_{0}$-equivalent solid angle; $\Omega_{\text {det. }}=S_{\text {det. }} / 1_{0}^{2}$ - solid angle of the photodetector; $\mathrm{S}_{\mathrm{det}}$ - area of the photodetector window; $1_{0}-$ the distance at which the photodetector is located from the radiation source.

The average power was calculated taking into account the emitting area and the radiation transmittance of the perforated electrode. The equivalent solid angle was taken equal to $\pi^{2}$ (for a cylindrical surface) [10].

Gas mixtures were prepared directly in the interelectrode space by successively injecting heavy inert gas xenon and light buffer helium gas "high" purity (GOST 1021). Cadmium diiodide $\left(\mathrm{CdI}_{2}\right)$ in an amount of $100 \mathrm{mg}$ was preloaded into the interelectrode space. Degassing of the electrode and the inner surface of the tube was carried out by heating them at a temperature of $50{ }^{\circ} \mathrm{C}$ and pumping out to a residual gas pressure of $1.3 \cdot 10^{-1} \mathrm{~Pa}$ by a $2 \mathrm{NVR}-5 \mathrm{DM}$ type foreline pump for $2 \mathrm{~h}$. The partial pressure of $\mathrm{CdI}_{2}$ vapors in the working mixtures was created due to heating of the mixture during the dissipation of the energy of a pulse-periodic discharge. Its values were estimated from reference data on the known temperature of the coldest point of the tube [11]. Its temperature was determined using a chromel - aluminum thermocouple. The gas pressures were measured with an exemplary membrane pressure gauge and a vacuum gauge. The error in measuring the gas pressures was no more than $1 \%$, and the partial pressure of cadmium diiodide vapor was $5 \%$.

The study of optical characteristics was carried out when stable electrical and emission characteristics of the plasma were achieved. A uniform discharge with no more than three filaments was visually observed. Filaments consist of two diffuse cones facing each other.

\section{SPECTRAL AND INTEGRAL CHARACTERISTICS}

Fig. 2 shows the overview radiation spectrum of a barrier discharge plasma from a mixture of cadmium diiodide vapor with helium at a pulse repetition rate of
$20 \mathrm{kHz}$, voltage amplitude at the electrodes, and current through a gas discharge gap of $10 \mathrm{kV}$ and $300 \mathrm{~A}$, respectively. The total pressure of the mixture is $250.024 \mathrm{kPa}$

Characteristic of this mixture is the presence of a system of spectral bands of the electronic-vibrational transition $\mathrm{B}^{2} \Sigma^{+}{ }_{1 / 2} \rightarrow \mathrm{X}^{2} \Sigma^{+}{ }_{1 / 2}$ of exciplex $\mathrm{CdI}^{*}$ molecules with a radiation maximum at a wavelength of $\lambda=650 \mathrm{~nm}, v^{\prime}=0-2 \rightarrow v^{\prime}=61.62$ [12], a steep increase in the intensity of these spectral bands from the side of the long-wave region and slow decline in the short-wave region. The edges of the spectral bands cover the wavelength range $470 \ldots 700 \mathrm{~nm}$. With a change in the repetition rate of the pump pulses in the range of $18 \ldots .20 \mathrm{kHz}$, the shape, range, and position of the maximum emission of the spectral bands do not change; only their intensity and the ratio of intensities in the band edges change. In addition to these spectral bands, radiation is also observed on the lines $\lambda=479 \mathrm{~nm}$ and $\lambda=509 \mathrm{~nm}$ of $\mathrm{Cd}$ atoms, the $5 \mathrm{p}^{3} \mathrm{P}_{0}-6 \mathrm{~s}^{3} \mathrm{~S}$ transitions $J=1-1$ and $J=2-1[13,14]$. With a change in the repetition rate of the pump pulses from 18 to $20 \mathrm{kHz}$, the radiation intensity in the spectral bands and lines increases by $10 \%$.

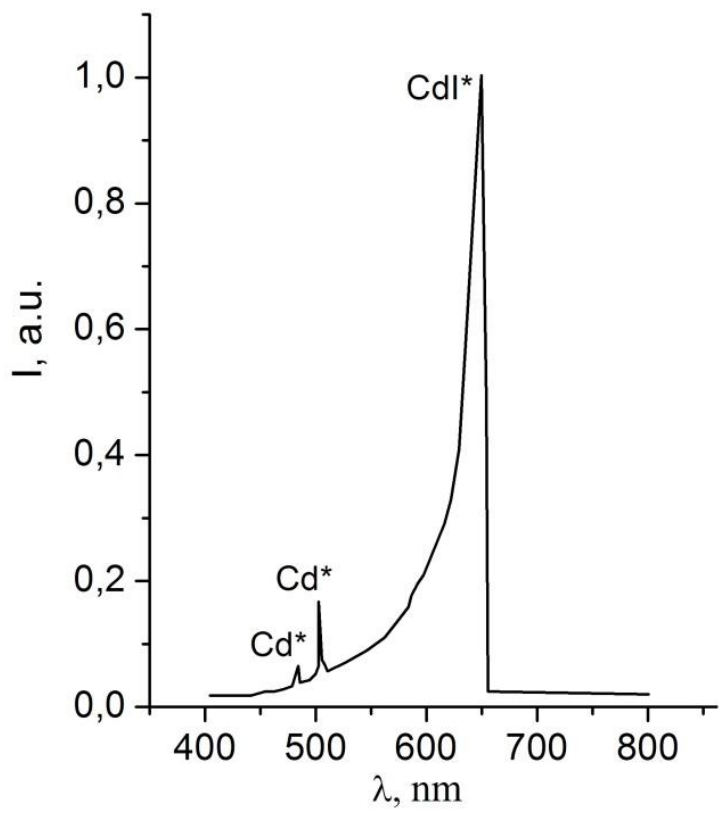

Fig. 2. Survey emission spectrum of a plasma of a barrier discharge on a CdI $\mathrm{Cl}_{2}$ He mixture. The spectrum was recorded 30 min after the ignition of the discharge. The repetition rate of the pump pulses is $f=20 \mathrm{kHz}$, the amplitude of the voltage and current is $U=10 \mathrm{kV}$ and

$I=300 \mathrm{~A}$, respectively. The total pressure of the mixture is $p-250.024 \mathrm{kPa}$

For a mixture with xenon (Fig. 3, the partial pressure of cadmium diiodide is $24 \mathrm{~Pa}$, the partial pressure of xenon is $4.05 \mathrm{kPa}$, the partial pressure of helium is $250 \mathrm{kPa})$ it is typical that in the plasma emission spectrum, in addition to the system of spectral transition bands $\left(\mathrm{B}^{2} \Sigma^{+}{ }_{1 / 2} \rightarrow \mathrm{X}^{2} \Sigma^{+}{ }_{1 / 2}\right) \lambda_{\max }=650 \mathrm{~nm} \mathrm{CdI}^{*}$ molecules, there are cadmium atom lines $\lambda=479 \mathrm{~nm}$ and $\lambda=509$ $\mathrm{nm}$ (transitions $5 \mathrm{p}^{3} \mathrm{P}_{0}-6 \mathrm{~s}^{3} \mathrm{~S}, \mathrm{~J}=1-1$ and $\mathrm{J}=2-1$ ), Xe atom lines $\lambda=823 \mathrm{~nm}, \lambda=458 \mathrm{~nm}$, and $\lambda=450 \mathrm{~nm}$ 
(transitions, and) [12-14]. Spectral bands and emission lines of a plasma of a barrier discharge on a mixture of cadmium diiodide vapor with helium, xenon for a pulse repetition rate of $18 \mathrm{kHz}$, their relative intensities $\left(\mathrm{J} / \mathrm{k}_{\lambda}\right)$ taking into account the spectral sensitivity of the recording system $\left(\mathrm{k}_{\lambda}\right)$, as well as the excitation energy, are given in Table.

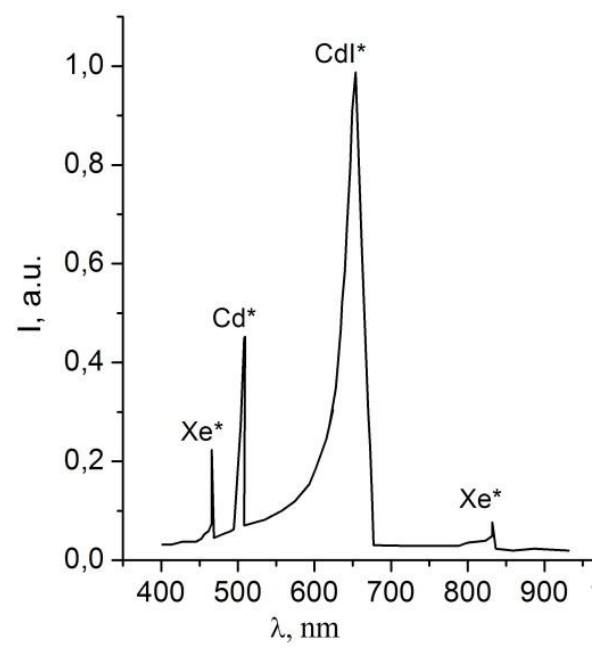

Fig. 3. Survey spectrum of radiation of a barrier discharge plasma on a mixture of

$\mathrm{CdI}_{2}: \mathrm{Xe}: \mathrm{He}=\sim 0.024: 4.05: 250 \mathrm{kPa}$. The spectrum was recorded $30 \mathrm{~min}$ after the ignition of the discharge.

The repetition rate of the pump pulses is $f=20 \mathrm{kHz}$, the voltage and current amplitudes are $U=10 \mathrm{kV}$ and $I=300 \mathrm{~A}$, respectively

Spectral bands and emission lines of working mixtures

\begin{tabular}{|c|c|c|c|c|c|c|}
\hline \multirow[b]{2}{*}{$\lambda, \mathrm{nm}$} & \multirow[b]{2}{*}{ 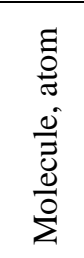 } & \multirow[b]{2}{*}{$\begin{array}{l}\mathrm{k}_{\lambda} \\
\text { a.u. }\end{array}$} & \multicolumn{2}{|c|}{$\mathrm{J} / \mathrm{k}_{\lambda}$, a.u. } & \multirow[b]{2}{*}{$\mathrm{E}_{\mathrm{B}}, \mathrm{eV}$} & \multirow[b]{2}{*}{ 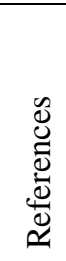 } \\
\hline & & & 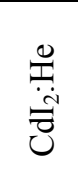 & 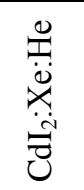 & & \\
\hline 458 & Xe I & 8 & - & 0.2 & 11.15 & [13] \\
\hline 479 & $\mathrm{Cd} \mathrm{I}$ & 13 & 0.82 & 0.25 & 6.39 & [13] \\
\hline 509 & $\mathrm{Cd} \mathrm{I}$ & 19 & 1.56 & 0.38 & 6.39 & [13] \\
\hline 650 & $\mathrm{CdI}$ & 57 & 2.8 & 0.88 & 5.0 & [15] \\
\hline 823 & Xe I & 20 & - & 0.1 & 9.82 & [13] \\
\hline
\end{tabular}

With a change in the repetition rate of the pump pulses from 18 to $20 \mathrm{kHz}$, the radiation intensity in the spectral bands and lines increases by $10 \%$. The radiation intensity of $\mathrm{CdI}^{*}$ molecules in a mixture of cadmium diiodide vapor and helium at a maximum of radiation at a wavelength of $\lambda=650 \mathrm{~nm}$ exceeds the radiation intensity of cadmium atoms at wavelengths of $\lambda=479.991 \mathrm{~nm}$ and $\lambda=508.582 \mathrm{~nm}$ by 3.4 and 1.8 times, respectively, and the radiation intensity of molecules $\mathrm{CdI}^{*}$ in a mixture of vapors of cadmium, xenon and helium diiodide at a radiation maximum at a wavelength of $\lambda=650 \mathrm{~nm}$ exceeds the radiation intensity: cadmium atoms at wavelengths $\lambda=479.991 \mathrm{~nm}$ and $\lambda=508.582 \mathrm{~nm}$, xenon atoms at wavelengths $\lambda=458 \mathrm{~nm}$ and $\lambda=823 \mathrm{~nm}$ in $3.5,2.3$, 4.4, 8.8 times, respectively (see Table). With an increase in the partial pressure of helium from 120 to $260 \mathrm{kPa}$, a nonmonotonic change in the radiation power of exciplex molecules of cadmium monoiodide is observed, a continuous increase in the range $120 \ldots 250 \mathrm{kPa}$, reaching a maximum value at $250 \mathrm{kPa}$ (Fig. 4) and a decrease with a further increase in helium pressure.

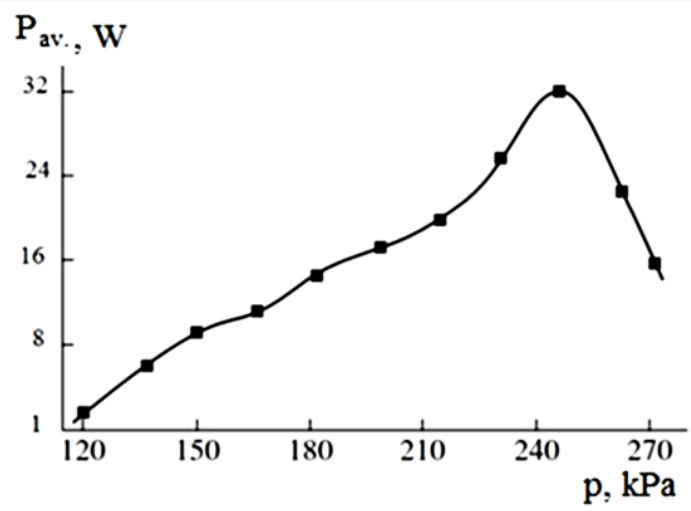

Fig. 4. The dependence of the average radiation power of exciplex cadmium monoiodide molecules on the partial pressure of helium. The amplitude of voltage and current is $U=10 \mathrm{kV}$ and $I=300 \mathrm{~A}$, respectively.

The repetition rate of the pump pulses is $f=20 \mathrm{kHz}$

Fig. 5 shows the results of the dependence of the radiation intensity of the exciplex molecules of cadmium monoiodide on the xenon partial pressures. The most intense radiation of molecules occurs at a partial xenon pressure of $4 \mathrm{kPa}$.

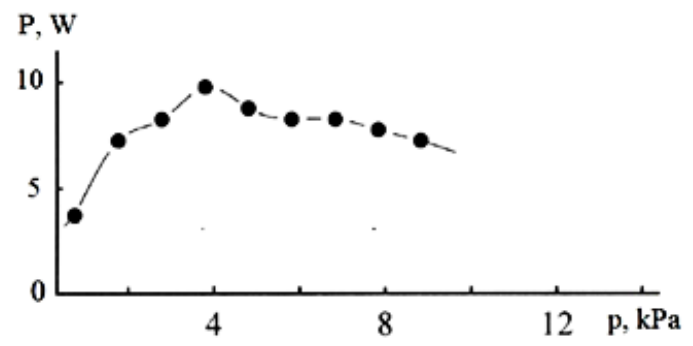

Fig. 5. The dependence of the average radiation power of exciplex cadmium monoiodide molecules on the xenon partial pressure in a mixture of cadmium diiodide vapor with helium and xenon. The partial vapor pressure of cadmium diiodide is $\sim 24 \mathrm{~Pa}$, and helium is $250 \mathrm{kPa}$.

The repetition rate of the pump pulses is $20 \mathrm{kHz}$

The dependence of the radiation power of cadmium monoiodide on the number of pump pulses for a component composition (the ratio of gas components was chosen optimal - at which the maximum radiation powers of $\mathrm{CdI}^{*}$ molecules are observed) is shown in Fig. 6. It is characteristic of it that the saturation of the radiation power for a mixture with xenon occurs earlier in time than for mixtures only with helium. In addition, there is a regularity - in a mixture of cadmium diiodide vapor with helium, the radiation power of $\mathrm{CdI}^{*}$ molecules is higher. 


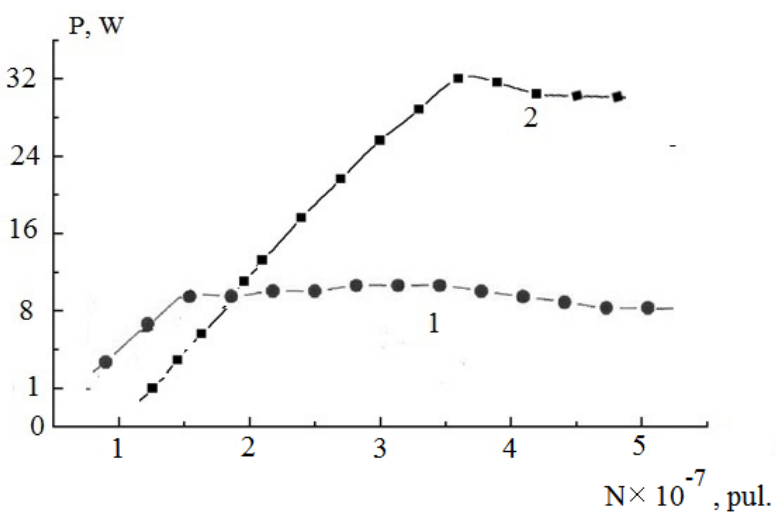

Fig. 6. The dependence of the average radiation power of cadmium monoiodide on the total number of pulses:

$1-\mathrm{CdI}_{2}: \mathrm{Xe}: \mathrm{He}=\sim 24 \mathrm{~Pa}: 4 \mathrm{kPa}: 250 \mathrm{kPa}$;

2 - a mixture of $\mathrm{CdI}_{2}: \mathrm{He}=\sim 24 \mathrm{~Pa}: 250 \mathrm{kPa}$.

The pump pulse repetition rate is $f=20 \mathrm{kHz}$

The emission of spectral bands with a maximum at a wavelength of $\lambda=650 \mathrm{~nm}$ of the electronic vibrational transition $\mathrm{B}^{2} \Sigma^{+}{ }_{1 / 2} \rightarrow \mathrm{X}^{2} \Sigma^{+}{ }_{1 / 2}$ of the $\mathrm{CdI}^{*}$ molecule in a gas discharge plasma on mixtures of cadmium diiodide vapor with xenon and helium occurs as a result of processes lead to the formation and destruction of the state of cadmium monoiodide, the main of which are [3, 18]:

$$
\begin{aligned}
& \mathrm{CdI}_{2}+\mathrm{e} \rightarrow \mathrm{CdI}_{2}\left({ }^{3,1} \Sigma_{\mathrm{u}}^{+}\right) \rightarrow \mathrm{CdI}\left(\mathrm{B}^{2} \Sigma^{+}{ }_{1 / 2}\right)+\mathrm{I}+\mathrm{e}, \\
& \mathrm{CdI}_{2}+\mathrm{e} \rightarrow \mathrm{CdI}_{2}\left({ }^{3,1} \Sigma_{\mathrm{u}}^{+}\right) \rightarrow \mathrm{CdI}\left(\mathrm{B}^{2} \Sigma^{+}{ }_{1 / 2}\right)+\mathrm{I}^{-}, \\
& \mathrm{CdI}\left(\mathrm{B}^{2} \Sigma^{+}{ }_{1 / 2}\right) \rightarrow \mathrm{CdI}\left(\mathrm{X}^{2} \Sigma^{+}{ }_{1 / 2}\right)+\mathrm{h} v, \\
& \lambda_{\text {Max. }}=650 \mathrm{~nm}, \\
& \mathrm{CdI}\left(\mathrm{B}^{2} \Sigma^{+}{ }_{1 / 2}\right)+\mathrm{M} \rightarrow \mathrm{CdI}\left(\mathrm{X}^{2} \Sigma^{+}{ }_{1 / 2}\right)+\mathrm{M}+\Delta \mathrm{E},
\end{aligned}
$$

where $\mathrm{M}$ is the concentration of $\mathrm{CdI}_{2}, \mathrm{Xe}, \mathrm{He} ; \Delta \mathrm{E}$ is the energy difference in the reaction.

Reactions (1) and (2) are the main sources of the formation of $\mathrm{CdI}^{*}$ exciplex molecules $[3,16]$. Electronvibrational transitions of $\mathrm{B}^{2} \Sigma_{1 / 2}^{+} \rightarrow \mathrm{X}^{2} \Sigma^{+}{ }_{1 / 2}$ of $\mathrm{CdI} *$ molecules lead to emission of spectral bands with a maximum intensity at a wavelength $\lambda_{\max }=650 \mathrm{~nm}$ (reaction 3). In the quenching reaction (4), an electron vibrational transition of the cadmium monoiodide molecule to the ground state occurs without radiation.

The emission of cadmium lines and xenon lines occurs due to reactions [19]:

$$
\begin{gathered}
\mathrm{CdI}_{2}+\mathrm{e} \rightarrow \mathrm{Cd}\left(5 \mathrm{p}^{3} \mathrm{P}^{0}\right)+\mathrm{I}+\mathrm{I}^{-}, \\
\mathrm{Cd}\left(5 \mathrm{p}^{3} \mathrm{P}^{0}\right) \rightarrow \operatorname{Cd}\left(6 \mathrm{~s}^{3} \mathrm{~S}^{0}, \mathrm{~J}=1-1\right)+\mathrm{h} v, \\
\lambda=479.991 \mathrm{~nm}, \\
\mathrm{Cd}\left(5 \mathrm{p}^{3} \mathrm{P}^{0}\right) \rightarrow \operatorname{Cd}\left(6 \mathrm{~s}^{3} \mathrm{~S}^{0}, \mathrm{~J}=2-1\right)+\mathrm{h} v, \\
\lambda=508.582 \mathrm{~nm}, \\
\mathrm{Xe}+\mathrm{e} \rightarrow \mathrm{Xe}+\mathrm{e}, \\
\lambda=458 \mathrm{~nm}, 823 \mathrm{~nm} .
\end{gathered}
$$

A sharp increase in the intensity of the emission spectral band of exciplex molecules of cadmium monoiodide from the side of the region in the spectrum with long wavelengths and its slow decrease in the region of short wavelengths (see Figs. 2, 3) is explained by the course of potential curves (excited $\mathrm{B}^{2} \Sigma^{+}{ }_{1 / 2}-$ state is shifted toward large internuclear distances relative to the $\mathrm{X}^{2} \Sigma^{+}{ }_{1 / 2}$ - state) and by processes of relaxation of the population of the upper vibrational sates of the excited electronic state, which occur faster than the electronvibrational transition to the main $\mathrm{X}^{2} \Sigma^{+}{ }_{1 / 2}$-state [20].

An increase in the intensity of the spectral emission bands of exciplex CdI* molecules, as well as the intensity of the spectral lines of cadmium and xenon atoms at an increased pulse repetition rate in the range of $18 \ldots 20 \mathrm{kHz}$, is caused by an increase in the number of excitation events of plasma components and, correspondingly, the number of radiation pulses per unit time, which fall into the registration system. In addition, an increase in the intensity of the emission spectral bands of exciplex $\mathrm{CdI}^{*}$ molecules and cadmium atoms is also caused by a change in the temperature of the working mixture (the dissipation power of the discharge energy increases with increasing pulse repetition rate [21] and, accordingly, the partial pressures of cadmium diiodide increase [11]). And this leads to an increase in the concentration of cadmium diiodide vapors and, ultimately, to different concentrations of excited $\mathrm{CdI} *$ molecules in the $\mathrm{B}^{2} \Sigma_{1 / 2}^{+}$-state, which leads to an increase in the radiation intensities in the spectral bands and lines $\lambda=479.991 \mathrm{~nm}$ and $\lambda=508.582 \mathrm{~nm}$.

The dependence of the radiation power on the partial pressure of helium and xenon (see Figs. 4, 5) is related to the fraction of the discharge energy that is spent on heating the working mixture [21]. Numerical simulation of specific discharge power losses due to elastic scattering of electrons by atoms and molecules for mixtures of cadmium diiodide with helium and xenon established that with an increase in the total pressure of the mixture from 120 to $270 \mathrm{kPa}$, the reduced electric field strength decreases from 137 to $64.5 \mathrm{Td}$.

This leads to an increase in the specific losses of the discharge power due to the elastic scattering of electrons by atoms and molecules (heating the mixture) and, accordingly, to an increase in the partial pressure of the cadmium diiodide vapor and the radiation intensity of $\mathrm{CdI}^{*}$ molecules. The presence of a maximum of power and its further decrease is caused by a decrease in the mean electron energy, and this, in turn, leads to a decrease in the rate constants of the dissociative excitation of the $\mathrm{B}^{2} \Sigma^{+}{ }_{1 / 2}-\mathrm{CdI} *$ states by electrons in processes (1) and (2). In addition, the process (4) contributes to a decrease in the radiation power in quenching the luminescence of cadmium monoiodide molecules by helium and xenon. The lower radiation power of exciplex $\mathrm{CdI}^{*}$ molecules in a mixture of cadmium diiodide, xenon and helium vapors (see Fig. 5) compared to a two-component mixture of cadmium diiodide vapor with helium (see Fig. 4) is caused by the fact that the discharge energy is spent on additional excitation channels of energy states, namely xenon atoms, and, accordingly, it is less spent on dissociative excitation of $\mathrm{B}^{2} \Sigma^{+}{ }_{1 / 2}$-states of $\mathrm{CdI}^{*}$ molecules by electrons (reactions 1 and 2), as well as the process of quenching the luminescence of cadmium monoiodide molecules by xenon (reaction 4). Numerical modeling revealed that the fraction of energy spent on the dissociative excitation of this state of mercury monoiodide molecules in a mixture of cadmium diiodide vapor with helium and with xenon is $33 \%$ less 
than the energy fraction in a mixture of cadmium diiodide vapor with helium.

The saturation of power for a mixture with xenon occurs earlier in time than for mixtures only with helium (see Fig. 6, curves 1 and 2) due to the different rate of dissipation of the discharge energy for a multicomponent plasma and which depends primarily on the probability of elastic collisions of electrons with plasma components, which for the mixture with the addition of xenon is higher [19]. To determine the quantitative characteristics of this regularity, it is necessary to carry out numerical calculations of the kinetics of the process of dissipation of the discharge energy in such a multicomponent mixture.

\section{CONCLUSIONS}

Thus, a study of the emission characteristics of a gas-discharge plasma of a barrier discharge in twocomponent and three-component mixtures (cadmium diiodide with helium and a small addition of xenon) revealed radiation in the visible and near infrared spectral ranges of exciplex molecules of cadmium monoiodide, cadmium atoms, xenon. The edges of the spectral bands cover the wavelength range of $470 \ldots 700 \mathrm{~nm}$ (systems of spectral bands of the electronic-vibrational transition $\mathrm{B}^{2} \Sigma^{+}{ }_{1 / 2} \rightarrow \mathrm{X}^{2} \Sigma^{+}{ }_{1 / 2}$ of exciplex CdI* molecules with emission maxima at wavelengths $\left.\lambda=650 \mathrm{~nm}, v^{\prime}=0-2 \rightarrow v^{\prime} '=61.62\right)$. In addition, there are cadmium atom lines $\lambda=479 \mathrm{~nm}$ and $\lambda=509 \mathrm{~nm}$ (transitions $5 \mathrm{p}^{3} \mathrm{P}^{0}-6 \mathrm{~s}^{3} \mathrm{~S}, \mathrm{~J}=1-1$ and $\mathrm{J}=2-1$ ), and in the three-component mixture, the atom lines $\mathrm{Xe}$ $\lambda=823 \mathrm{~nm}, \lambda=458 \mathrm{~nm}$, and $\lambda=450 \mathrm{~nm}$.

The radiation power of the exciplex cadmium monoiodide molecules in two component mixtures is higher than the radiation power in the three component mixture, which is explained by the lower value of the discharge power that is introduced in the excitation of the $\mathrm{B}^{2} \Sigma^{+}{ }_{1 / 2^{-}}$state of the $\mathrm{CdI}^{*}$ exciplex molecules due to the presence of additional channels for the loss of discharge power in the vapor mixture of cadmium diiodide, xenon and helium.

As the pump pulse repetition rate increases to $20 \mathrm{kHz}$, the radiation power of the spectral bands, cadmium and xenon lines in the studied mixtures increases. These changes are caused both by an increase in the number of radiation pulses per unit time (due to an increase in the number of acts of excitation of the plasma components) that enter the recording system, and by an increase in the partial pressures of cadmium diiodide due to an increase in the rate of dissipation of the discharge energy.

Different rates of achieving saturation of the radiation power depending on the time the mixture was used are caused by different rates of dissipation of the discharge energy in two component and three component mixtures.

No noticeable (within the measurement error of $10 \%$ ) changes in the radiation power of exciplex CdI* molecules (after reaching their maximum values) were not observed for $5 \cdot 10^{7}$ pump pulses for the studied mixtures.

\section{REFERENCES}

1. D.P. Greene, J.G. Eden. Discharge pumped ZnI $(599 . .606 \mathrm{~nm})$ and $\mathrm{CdI}(653 \ldots 662 \mathrm{~nm})$ amplifiers // Appl. Phys. Lett. 1983, v. 42, № 1, p. 20-22.

2. A.N. Konoplev, V.A. Kelman, V.S. Shevera. Investigation of the radiation of a pulsed discharge in mixtures of $\mathrm{ZnI}_{2}, \mathrm{CdI}_{2}$, and $\mathrm{HgI}_{2}$ with helium and neon // Jh. of Applied Spectroscopy. 1983, v. 39, № 2, p. 315317.

3. V.S. Shevera, A.N. Malinin, A.K. Shuaibov. Investigation of the excitation and quenching of the $\mathrm{B}^{2} \Sigma^{+}{ }_{1 / 2}$ state of $\mathrm{CdI}^{*}$ in a pulsed dielectric discharge // Jh. of Applied Spectroscopy. 1983, v. 39, № 3, p. 476.

4. S.P. Bogacheva, A.N. Konoplev, A.I. Khodanich, V.S. Shevera. The population of excited atoms and molecules in a gas-discharge $\mathrm{Ne}-\mathrm{CdI}_{2}$ plasma // Ukr. Physical Journal. 1992, v. 37, № 5, p. 678-682.

5. A.N. Malinin, A.V. Polyak. Optical characteristics of barrier discharge plasma based on mixtures of cadmium diiodide vapors with gases // Optics and Spectroscopy. 2005, v. 99, p. 912-917.

6. G. Zissis, S. Kitsinelis. State of art on the science and technology of electrical light sources: from the past to the future // J. Phys. D: Appl. Phys. 2009, v. 42, p. 173001.

7. A.M. Boychenko, M.I. Lomaev, A.N. Panchenko, et al. Ultraviolet and vacuum-ultraviolet excilamps: physics, technology and applications. Tomsk: STT, 2011.

8. U. Kogelschatz. Ultraviolet excimer radiation from nonequilibrium gas discharges and its application in photophysics, photochemistry and photobiology // J. Opt. Technol. 2012, v. 79, № 8, p. 484-493.

9. R.A. Sapozhnikov. Theoretical photometry. M.: "Energy", 1977.

10. I.K. Kikoin. Tables of physical quantities. Directory. M.: "Atomizdat", 1976.

11. R.W. Pears, A.G. Gaydon. The identification of molecular spectra. Ldn: Chopman Holl LTD, 1963.

12. A.N. Zaydel, V.K. Prokofiev, S.M. Raysky, V.A. Slavny, E.Ya. Schreider. Tables of spectral lines. M.: "Nauka", 1977.

13. V.E. Prokopyev, A.S. Yatsenko. Energy levels and radiative transitions of neutral atoms // Preprint of IAE SB AS USSR. Novosibirsk, 1981, № 161, p. 52.

14. A.N. Konoplev, N.N. Chavarga, V.N. Slavik, V.S. Schevera. Dissocative Excitation of $\mathrm{CdI}_{2}$ by Electron Impact // Letters in ZhTF. 1989, v. 15, № 22, p. 48-51.

15. G.J.M. Hagelaar, L.C. Pitchford. Solving the Boltzmann equation to obtain electron transport coefficients and rate coefficients for fluid models // Plasma Sources Sci Technol. 2005, v. 14, p. 722.

16. https://www.bolsig.laplace.univ-tlse.fr.

17. A.N. Konoplev, V.N. Slavik, V.S. Schever. Dissocative ionization of $\mathrm{CdI}_{2}$ molecules by electron impact // Letters in ZhTF. 1990, v. 16, № 19, p. 86-89.

18. Yu.M. Smirnov. Inelastic collisions of slow electrons with cadmium (II) iodide molecules // High Energy Chemistry. 2000, v. 34, № 6, p. 405-410. 
19. V.V. Datsyuk, I.A. Izmailov, V.A. Kochelap. Vibrational relaxation of excimers // Physics-Uspechi. 1998, v. 41, p. 379-402.
20. Yu.P. Raiser. Physics of gas discharge. M.: «Nauka», 1987.

\section{ЭМИССИОННЫЕ ХАРАКТЕРИСТИКИ ГАЗОРАЗРЯДНОЙ ПЛАЗМЫ НА СМЕСЯХ ПАРОВ ДИЙОДИДА КАДМИЯ, ГЕЛИЯ И КСЕНОНА}

\section{А.А. Малинина, А.Н. Малинин}

Приведены результаты исследования спектральных, интегральных и ресурсных характеристик излучения газоразрядной плазмы на многокомпонентных смесях (дийодид кадмия с гелием и малыми добавками ксенона). Создание газоразрядной плазмы и возбуждение компонент рабочей смеси осуществлялось импульсно-периодическим (частота следования импульсов 18...20 кГц, длительность импульсов 150 нс) барьерным разрядом. Выявлено излучение в видимой области спектра эксиплексных молекул монойодида кадмия, атомов кадмия, ксенона. Установлены закономерности в изменениях эмиссионных характеристик плазмы в зависимости от частоты следования импульсов накачки, компонентного и количественного составов смесей. Данные исследований представляют интерес для создания газоразрядного источника, который излучает одновременно в фиолетовом, зеленом, красном и инфракрасном спектральных диапазонах.

\section{ЕМІСІЙНІ ХАРАКТЕРИСТИКИ ГАЗОРОЗРЯДНОЇ ПЛАЗМИ НА СУМІШАХ ПАРІВ ДИЙОДИДУ КАДМІЮ, ГЕЛІЮ ТА КСЕНОНУ}

\section{А.А. Малініна, А.Н. Малінін}

Наведено результати дослідження спектральних, інтегральних і ресурсних характеристик випромінювання газорозрядної плазми на багатокомпонентних сумішах (дийодид кадмію з гелієм і малими добавками ксенону). Створення газорозрядної плазми і збудження компонент робочої суміші здійснювалося імпульсно-періодичним (частота слідування імпульсів $18 . .20$ кГц, тривалість імпульсів 150 нс) бар'єрним розрядом. Виявлено випромінювання у видимій області спектру ексиплексних молекул монойодиду кадмію, атомів кадмію, ксенону. Встановлено закономірності в змінах емісійних характеристик плазми в залежності від частоти слідування імпульсів накачки, компонентного і кількісного складів сумішей. Дані досліджень представляють інтерес для створення газорозрядного джерела, який випромінює одночасно у фіолетовому, зеленому, червоному і інфрачервоному спектральних діапазонах. 